\title{
HE.SU.TECH. LABORATORY: ACADEMIC RESEARCH COMBINED WITHTHE PRACTICE APPLIED IN THE DOCUMENTATION, REPRESENTATION, AND PRESERVATION OF THE ARCHITECTURAL HERITAGE - THE CASE OF THE PALLADIO VILLA FORNI CERATO

\author{
LABORATÓRIO HE.SU.TECH: PESQUISA ACADÊMICA COMBINADA COM A PRÁTICA \\ APLICADA NA DOCUMENTAÇÃO, REPRESENTAÇÃO E PRESERVAÇÃO DO PATRIMÔNIO \\ ARQUITETÔNICO - O CASO DA VILLA FORNI CERATO DE PALADDIO
}

\author{
Andrea Adami ${ }^{1}$, Luigi Fregonese ${ }^{1}$, Simone Helena Tanoue Vizioli ${ }^{2}$, Laura Taffurelli ${ }^{1}$, \\ Daniele Treccani ${ }^{1}$, Olga Rosignoli ${ }^{1}$, Jacopo Helder ${ }^{1}$
}

\begin{abstract}
:
This article runs an in-depth examination of documentation, representation and conservation praxis of Architectural Heritage in the field of applied academic research. The focus is put on technological advances in digital documentation applied to Cultural Heritage. The architectural survey is one of the first actions taken in the knowledge process of an asset and, as such, it becomes essential for subsequent conservation, restoration and management operations. This paper describes an experience of integrated digital surveying techniques for the digitalization of an architecture by Andrea Palladio: Villa Forni Cerato. This experience has been carried out by the Heritage Survey Technology (HE.SU.TECH.) Group, from Politecnico di Milano - Polo di Mantova that has been carrying out research and consulting activities with institutions related to Italian Heritage since 2000. The case of Villa Forni Cerato is particularly interesting because, in this instance, digitization was integrated with other documental sources. The survey of the villa required the integration of all the different technologies used in the geomatic field for cultural HeritageThis case study, in particular, became an opportunity to test photogrammetric techniques with different photographic sets, acquired both from the ground and by means of Unmanned Aerial Systems (UAS). This work has been the subject of discussion within the exchange project between the two universities: Politecnico di Milano and Universita di San Paolo.
\end{abstract}

KEYWORDS: Cultural Heritage; 3D survey; Photogrammetry; Laser scanning; HBIM.

\section{RESUMO:}

Este artigo traz um estudo aprofundado sobre documentação, representação e práxis de conservação do patrimônio arquitetônico no campo da pesquisa acadêmica aplicada. A ênfase são os avanços tecnológicos na documentação digital aplicada ao Patrimônio Cultural. Destaca-se a importância em se conciliar o conhecimento da pesquisa acadêmica com o trabalho técnico aplicado. O mapeamento arquitetônico é uma das primeiras ações realizadas no processo de conhecimento de um bem e, como tal, ele torna-se imprescindível para as subsequentes operações de conservação, restauração e gestão. Este artigo apresenta uma experiência de técnicas integradas de mapeamento digital para a digitalização de uma arquitetura de Andrea Palladio: a Villa Forni Cerato. Esta experiência foi realizada pelo Grupo de Pesquisa Heritage Survey Technology (HE.SU.TECH.) do Politecnico di Milano - Polo di Mantova que desenvolve atividades de pesquisa e consultoria com instituições ligadas ao patrimônio italiano desde 2000. O caso da Villa Forni Cerato é particularmente interessante porque, neste caso, a digitalização foi integrada com outras fontes documentais, tais como as plantas e secções originais da própria Villa. O levantamento da Villa exigiu a integração de muitas tecnologias diferentes usadas no campo geomático para o Patrimônio Cultural. Este estudo de caso, em particular, tornou-se uma oportunidade para testar técnicas fotogramétricas com diferentes conjuntos fotográficos, adquiridos tanto do solo como por meio de Sistemas Aéreos Não Tripulados (UAS). Este trabalho tem sido objeto de discussão dentro do projeto de intercâmbio entre as duas universidades: Politécnico de Milão e Universidade de São Paulo.

PALAVRAS-CHAVE: Patrimônio Cultural; Mapeamento 3D; Fotogrametria, Digitalização a laser; HBIM.

Fonte de Financiamento:

Fundação de Amparo à

Pesquisa do Estado de São

Paulo; Politécnico di Milano

Conflito de Interesse:

Declara não haver.

Ética em Pesquisa:

Declara não haver necessidade.

Submetido em: 04/07/2020 Aceito em: 29/12/2020

How to cite this article:

ADAMI, A. et. al., HE.SU.TECH. laboratory: academic research combined with the practice applied in the documentation, representation, and preservation of the architectural heritage - the case of the Palladio Villa Forni Cerato. Gestão \& Tecnologia de Projetos. São Carlos, v16, n3, 2021. https://doi.org/10.11606/gtp.v16i3. 


\section{INTRODUCTION}

This article belongs to the context of the current technological progress in the field of digital documentation of Cultural Heritage. "Documentation represents an important and essential part in the process of heritage and memory conservation since every activity to be developed, both in the conservation and restoration of historical sites and monuments, requires its registration as complete and accurate as possible" (AMORIM, GROETELAARS, 2008). In addition to the importance Ruskin (2008) attached to the issue of maintenance, an old building needs to be preserved with particular care; it needs to be protected from the disruption time causes.

The aim of this article is to highlight the importance of reconciling academic research knowledge with applied technical work in the field of 3D architectural heritage documentation; this is obtained by analyzing a practical case in which an academic laboratory has worked on a UNESCO Cultural Heritage Site, Villa Forni Cerato, in the province of Vicenza, Italy. The construction of the building is attributed to architect Andrea Palladio and dated around 1565. Villa Forni Cerato Foundation, current manager of the property, has undertaken an important action of enhancement of the architectural complex, through in-depth studies, investigations, restoration and re-functionalization. The HE.SU.TECH. (Heritage Survey Technology) group, from Politecnico di Milano, has been part of this process by dealing with the geometric survey of the villa, during which all the most recent techniques and methodologies of Geomatics were used. The objective was to produce the survey documentation to be shared with all the other operators involved in the conservative restoration: plans, elevations, sections on a 1:50 scale, and HBIM (Historical Building Information Modeling) model of the building.

This example was presented in the workshop "Fotogrametria + Patrimônio", organized in April 2019 by N.elac - IAU USP (Núlceo de Pesquisa em Estudos de Linguagem em Arquitetura e Cidade - IAU USP) during the report entitled: "Photogrammetry for the valorization of Cultural Heritage: principles and applications for documentation and communication". Since 2009 an International Cooperation Agreement between Instituto de Arquitetura e Urbanismo of the University of São Paulo (IAU USP) and Politecnico di Milano (POLIMI) is active. Notably during the Colloquium Brazil - Italy promoted by N.elac IAU USP, in 2017, Prof. Andrea Adami from POLIMI and one of the coordinators of the HE.SU.TECH. group, went to Brazil to participate to the workshop, thus starting the first exchange experiences between the two groups (VIZIOLI et al, 2019)

The HE.SU.TECH. group is part of the Interdepartmental Research Laboratory MantovaLab of Mantua Campus of Politecnico di Milano. Among the various activities it conducted over the years (from the foundation of the Mantua Campus) the following research projects stand out: the photogrammetric survey at scale 1: 1 of the mosaic floor of St Mark's Basilica, Venice and St Mark's 3D project of a BIM system for the conservation and enhancement of the mosaics of the Basilica; 3D surveys of the finding and the architecture found during archaeological excavations for the Naples underground infrastructure; survey of the damages after the earthquake of 2012, of the churches of the Diocese of Mantua; documentation and survey of the conservation state of the Villa Palladiana Forni Cerato in Vicenza.

The paper begins with the description of the Villa Palladiana and its characteristics. Then follows a description of the survey operations, from the topographic network materialization to the laser-scanner use. The following chapter explains in detail the photogrammetric survey, comparing the one carried out from the ground and the one carried out by a drone, highlighting similarities and differences. In the final section, a comparison is made between the drawings of the villa made by architects Francesco Muttoni and Ottavio Bertozzi Scamozzi and its current 
configuration. The last chapter describes the modeling, still in progress, of the villa through a parametric approach within the Autodesk Revit software.

\section{VILLA FORNI CERATO}

Villa Forni Cerato (Figure 1) represents a very particular case within Andrea Palladio's production. In fact, Palladio did not design the new villa, but dedicated himself to the transformation of a pre-existing building. Moreover, this is one of the few Palladio villas, together with the house of the notary Cogollo, designed for a rich but not noble proprietary. The owner, in fact, was Girolamo Forni, a wealthy wood merchant and supplier of many Palladio's building sites.

Academics do not entirely agree on the attribution of the villa to Palladio (CEVESE, 1990), since some features are not typical of the architect's production: the planimetry is very simple and the proportions of the environments are not those typically used by Palladio. However, all this can be attributed to the fact that the villa is a renovation project. Typical features of Palladio's work are, instead, the serliana, with the columns reduced to sharp stereometric pillars according to the limited width of the loggia (probably sized on the pre-existing hall) or the frieze reduced to a simple band under the cornice. The elevation of the loggia, moreover, is conceptually identical to that of the Cogollo house, once again connecting these two remarkable buildings.

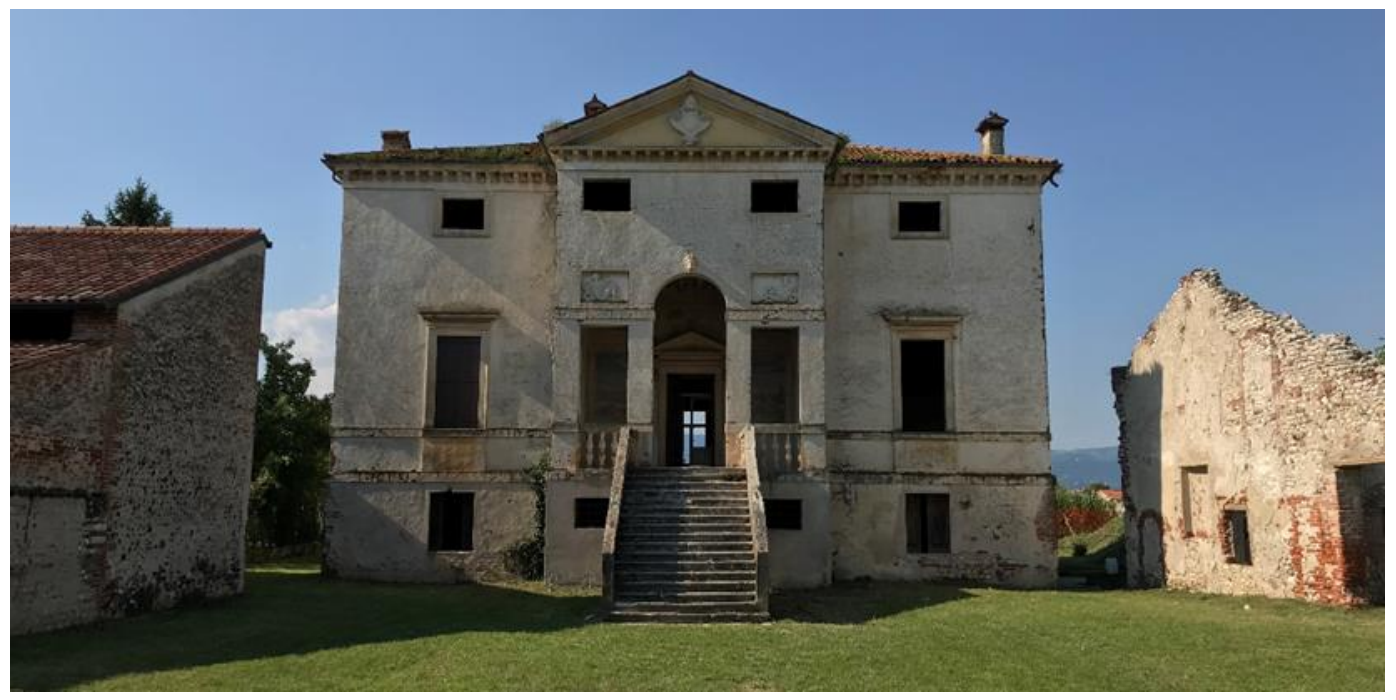

The building presents a rectangular footprint of modest dimensions and has the typical distribution structure of the Venetian palace: a tripartite system with a central room dedicated to the most representative functions. The villa is distributed on three floors: on the ground floor, there are services such as the kitchen, pantries and dwellings for servants; on the main floor, the residence of the owner and his family and finally the attic for the staff.

Almost completely stripped out of the rich sculptural decoration, a partly documented work by Alessandro Vittoria, the villa has been in a state of abandonment for several years. The rustic neighbors and the colombara (the place where pigeons were bred) are ruined. Of the original splendor, survive only the faded frescoes in the loggia depicting Roman ruins, two beautiful stone fireplaces (second half of the sixteenth century) and the head of Medusa, key of the serliana arch of the loggia, also attributed to Alessandro Vittoria.
Figure 1. The villa in state of abandonment prior to the conservation and restoration works.

Source: HE.SU.TECH., 2018. 
The aforementioned original drawings of the villa are particularly interesting. The first drawing that has come down to us is the one made by Francesco Muttoni in 1740. In the first book about his production (MUTTONI, 1740, Volume I, "Indice delle Città, Castelli e Ville"), he describes "many of Andrea Palladio's architectural factories [...] with the addition of several plates with annotations indicating how they were built from their beginning to the present". Among these, he includes Villa Forni Cerato, by the name of "Casino Ceratti" di Montecchio Precalcino. The drawing represents the plan of the main floor and the main elevation.

A second document is that contained in the work of the architect Ottavio Bertotti Scamozzi of 1778, titled "Le fabbriche e i disegni di Andrea Palladio" (BERTOZZI SCAMOZZI, 1778). There are three plates concerning the villa that represent the central elevation, the longitudinal section (with details of the cornice and the entrance door) and the plan of the main floor (Figure 2).

Figure 2. 0. Bertotti Scamozzi, plan, elevation and section of villa Forni Cerato (from Le Fabbriche e i disegni di Andrea Palladio, Vicenza, for Francesco Modena, 1778, II).

Source: https://it.wikipedia.org/wiki/Vill a_Forni_Cerato. Acess in 13 jan 2021.
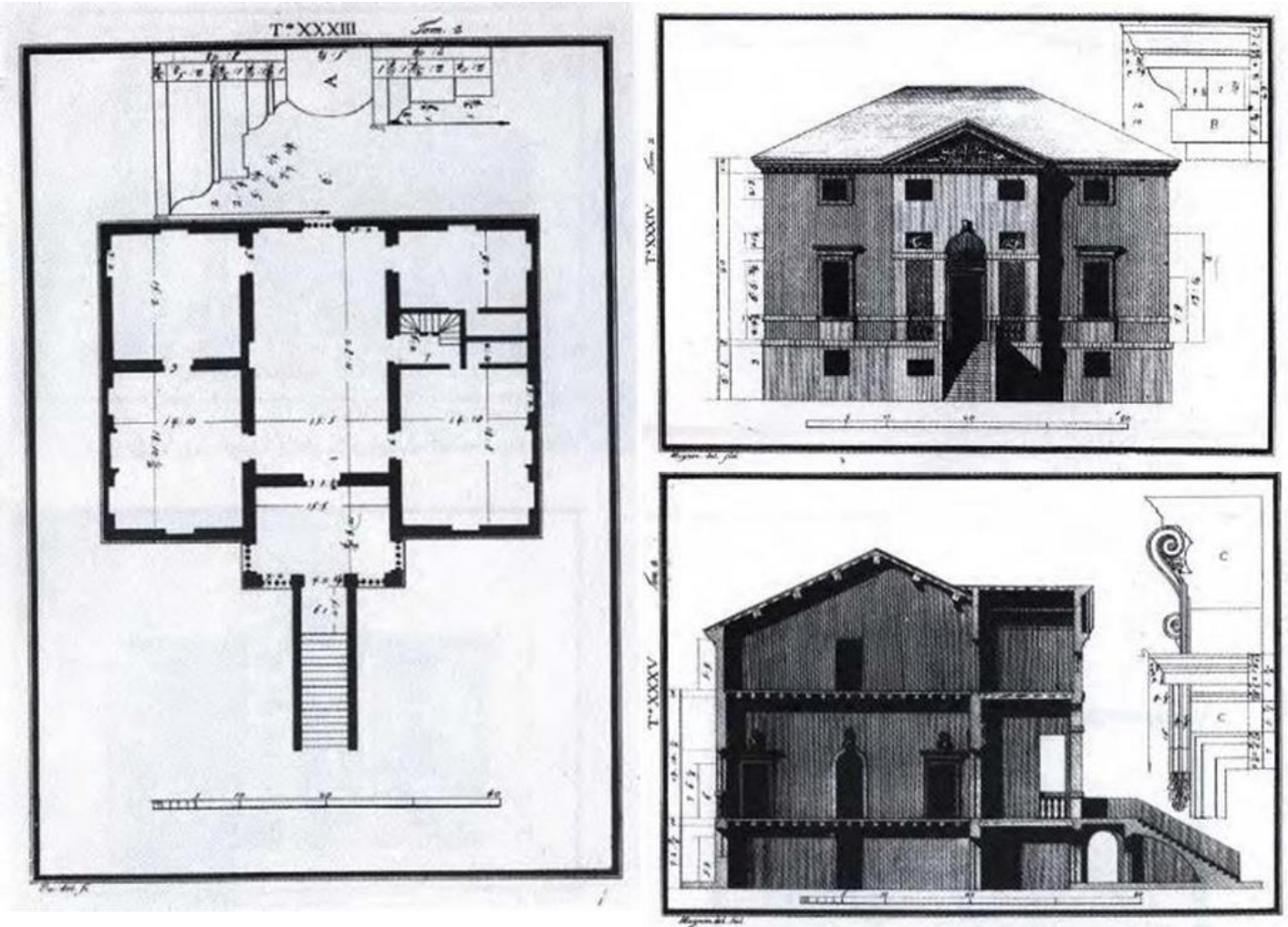

\section{ARCHITECTURAL SURVEY: TOPOGRAPHY AND LASER SCANNING}

During the architectural survey of Villa Forni Cerato we used the latest technologies offered by Geomatic sciences: laser scanning and terrestrial and aerial photogrammetry.

The previous experiences conducted by the research group have shown that, even including new technologies, the topographic approach guarantees the best results (FREGONESE et al., 2018). Nowadays, the market offers systems and tools that aim to better the automation of processes and ease the task of the operator. Iterative Closest Point (ICP) point clouds recording systems, automatic georeferencing systems, integration of images and vector data to produce colored point clouds work well when taken individually. However, when trying to integrate these different methods together automatically, errors (often related to the layout acquisition 
or to the geometry of the objects themselves) are observed. The solution to this problem is given, in this case, by topography. Using the total station, it is, in fact, possible to materialize through significant points (marked with topographic nails) a local reference system to which all operations can be referred. In this way, the ground laser scanning survey, the ground photogrammetric survey and the drone survey will be georeferenced in a unique system where the data, therefore, will be truly integrated.

The topographic network has been achieved with the Leica TS30 total station. The network has been developed on each floor of the villa, and the connections between the floors have been made through the windows, in order to minimize errors. The total station recorded the points of the network, the coordinates of targets needed for laser scanning workflow and those for the photogrammetric rendering of the rooms and façades, and also the points for georeferencing the photogrammetric models of the roof.

Although its use is quite recent (last 20 years), the principles of operation of terrestrial laser scanner (TLS) closely recall that of the total station: it measures horizontal angles, vertical angles and distances of points belonging to the surfaces of the surveyed objects. Anyway, the approach is very different: the classical topography uses a small number of points, chosen very carefully and detected manually. The laser scanning method, on the other hand, favours automation of the process and acquires a very large number of points on all surfaces (STYLIANIDIS; REMONDINO, 2018).

In the villa, the laser scanning survey has been realized with the Leica HDS 7000 scanner, a terrestrial laser scanner based on phase-shift measurement, with a 3D precision on the single point of about $3 \mathrm{~mm}$ and an acquisition speed up to $1.000 .000 \mathrm{pts} / \mathrm{sec}$. The scanner only detects the position of the point in addition to the intensity value (signal response after reflection on the object), so it can provide geometric information, but not information about the real color of the object. For the entire villa, 65 scans were taken, divided between exterior, ground floor, first floor and attic. In addition, the cellars and the remains of the surrounding buildings were also digitized. The scans were carried out with an average resolution of $3 \mathrm{~mm}$ at a $10 \mathrm{~m}$ distance from the center of the instrument, so to have a sufficient density of points for the representation scale 1:50.

All scans were georeferenced in the topographic reference system with Leica Cyclone software using black/white checkerboard targets, which were also detected topographically. All registered point clouds thus form a very high-resolution point database (Figure 3 ) that can be analysed, measured and sectioned to obtain 2D and 3D representations of the villa and its context. 
Figure 3. Laser scanning survey result. The different tones of grey are related to the intensity of the points

Source: HE.SU.TECH., 2018.

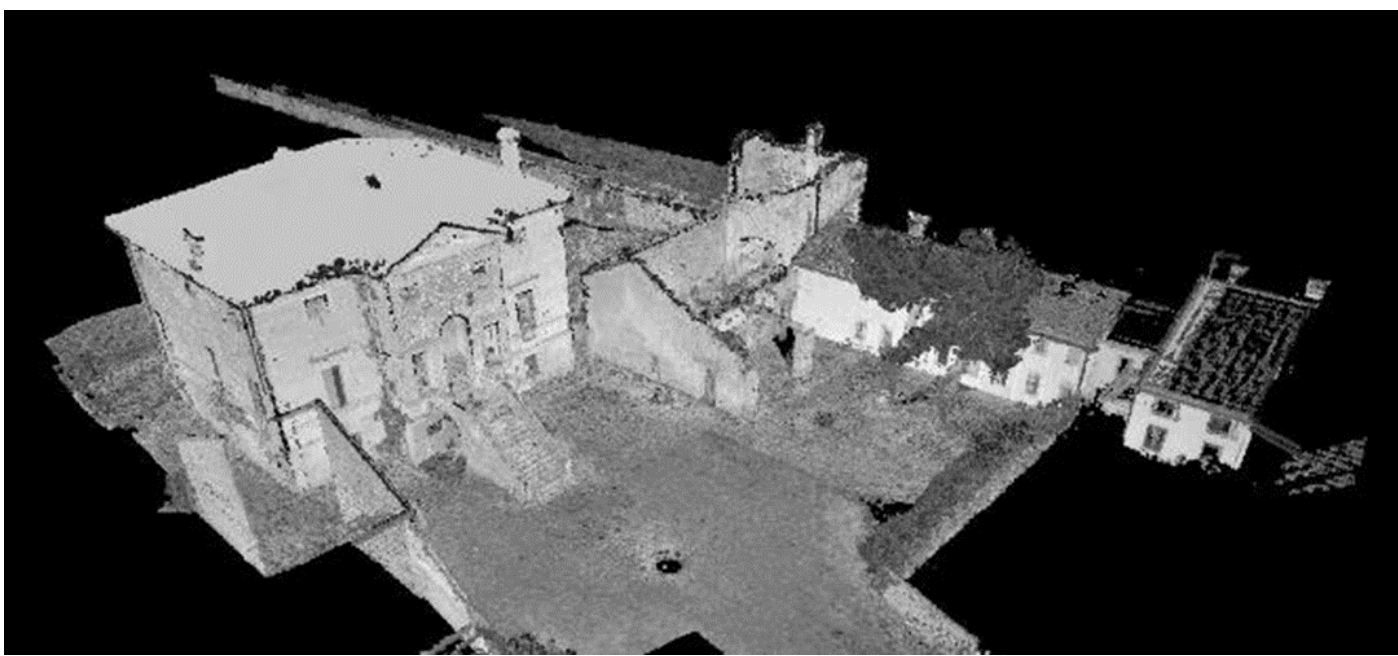

\section{PHOTOGRAMMETRIC SURVEY}

In the context of historical heritage, of which Villa Forni Cerato is an example, photogrammetry is very effective not only because it provides information on the geometry of architecture, but also because it allows the study of its state of conservation through color.

Digital photogrammetry in the last 10 years has been the protagonist of an important development thanks to the integration of algorithms typical of photogrammetry and others from the computer graphics sector (REMONDINO et al., 2014). Multi-image systems, based on structure-from-motion and dense-stereo-matching algorithms, allow to reconstruct a real space through photographs acquired according to well defined geometric acquisition schemes. The photogrammetric models, thus constructed, are then scaled and georeferenced according to the coordinates of the photogrammetric targets and can be sectioned to obtain the different representations (Figure 4). From the models, moreover, passing through the mesh, it is also possible to extract the orthophotos of the surfaces: orthogonal projections, with the characteristics of a photograph (FASSI; CAMPANELLA; 2017). In this way, it is possible to capture the state of conservation of the surfaces, maintaining a precise and accurate metric reference.

The survey of the villa by photogrammetry has highlighted some problematic aspects. In the interiors, in fact, the lack of power supply prevented the use of lamps and the like and therefore the photographs were acquired with only ambient light. In the final point clouds, the same area, acquired in different scans, has different colors, due to the presence of windows or openings.

Another problem concerned the façades. Being quite high (about 20,5 meters) and, in the case of the side façades, as there was little space available, it was decided to carry out the survey by comparing two different methods. Always using the photogrammetric method, two different photographic sets were used, one from the bottom and one from the drone, finally comparing the results. 

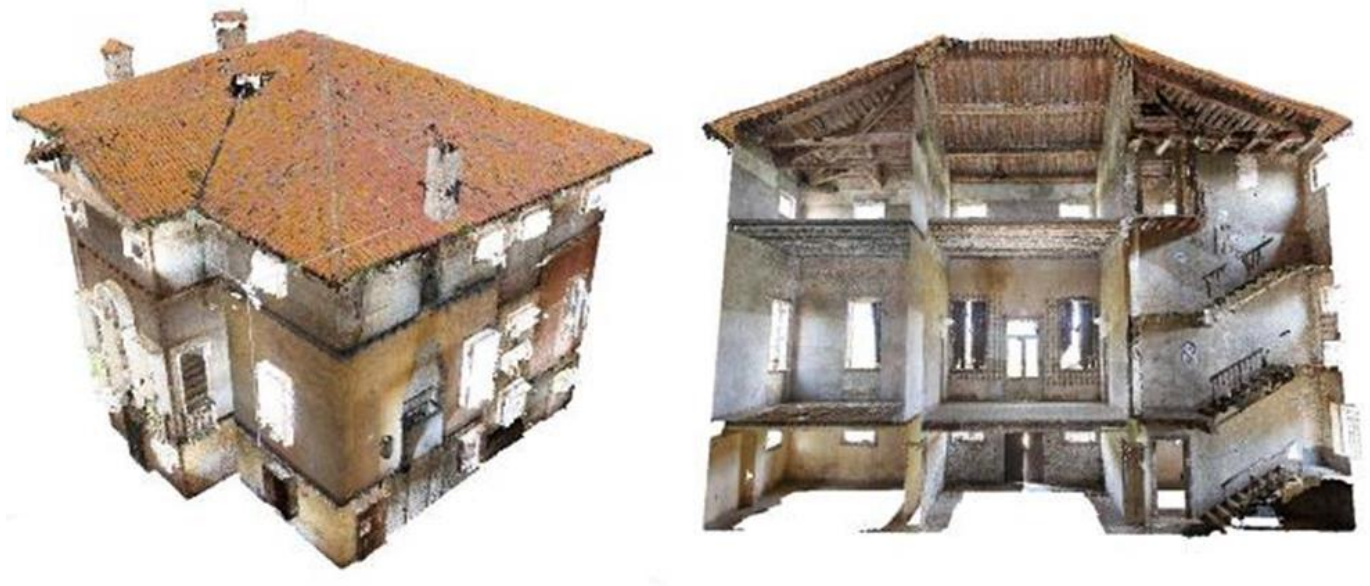

Specifically, the façades were surveyed by classical ground photogrammetry, by UAS photogrammetry and by laser scanning. According to the desired scale of representation, 1:50, all the data has been acquired to guarantee that result. The Ground Sample Distance (GSD) of photogrammetric acquisition has been set to a minimum of $2 \mathrm{~mm}$. According to real operative conditions, camera positions and distances from the building where such that the GSD for the acquired photos was $1 \mathrm{~mm} /$ pixel for ground photogrammetry and $2 \mathrm{~mm} /$ pixel for UAS photogrammetry.

We acquired images with an overlapping of 70-80\% in both directions in order to guarantee a good automatic alignment performed in Agisoft Metashape software.

The camera used for ground photogrammetry was a Canon Eos 5D Mark III with 85 mm lens. We decided to use $85 \mathrm{~mm}$ lens in order to acquire many details even in the upper part of the façade (with the disadvantage of having to acquire many pictures, more than necessary, in the lower part). We took 296 photos with the camera. As we did not have a lifting platform, all the images were acquired from the ground. This implied that only a strip of images was orthogonal to the façade and for the other images, the tilt angle was different according to the different part of the façade to be acquired.

The drone used was a DJI Spark with a lightening kit (the camera mounted has $4.49 \mathrm{~mm}$ lens). This UAS, according to the Italian legislation at the time of the survey, was very advantageous. Being under $300 \mathrm{~g}$, it could fly anywhere and it was not necessary to have a pilot license. We took 625 photos from the UAS. The drone flight was piloted so that pictures were acquired, as much as possible, in orthogonal to the façade. The piloting was only manually, and we had to consider the effect of wind and the difficulty to stay always parallel to the façade.

\begin{tabular}{|l|l|l|}
\hline & $\begin{array}{l}\text { Ground } \\
\text { Canon Eos 5D Mark III })\end{array}$ & $\begin{array}{l}\text { UAS } \\
\text { DJI Spark }\end{array}$ \\
\hline Number of photos & 296 & 625 \\
\hline Resolution & $5760 \times 3840$ pixels & $3968 \times 2976$ pixels \\
\hline Sensor size & $23 \mathrm{MP}(36 \times 24 \mathrm{~mm})$ & $12 \mathrm{MP}(6,17 \times 4,56 \mathrm{~mm})$ \\
\hline Lens & $85 \mathrm{~mm}$ & $4.49 \mathrm{~mm}$ \\
\hline Ground Sample Distance (GSD) & $1 \mathrm{~mm} /$ pixel & $2 \mathrm{~mm} /$ pixel \\
\hline
\end{tabular}

Figure 4. The result of photogrammetric survey. In the point clouds, each single point is characterized also by the real color from photos.

Source:

HE.SU.TECH., 2018.
Table 1. summarizes the main features of photos taken during the survey. As evident, the most relevant difference between ground and UAS photogrammetry is related to the sensor size. The sensor mounted on UAS has a half-resolution respect the camera used for ground photogrammetry. Source: HE.SU.TECH., 2018. 
We followed the typical photogrammetry workflow: the acquired photos were imported in Agisoft Metashape, where they were oriented up to the calculation of the dense point clouds. In particular, the computation parameters used for both the projects are the following. For image alignment we used, in both cases, an accuracy set to high, with 40.000 key points limit and 4.000 tie points limit. The two images sets were georeferenced and scaled by using the same 7 points as Ground Control Points (GCP), which coordinates were surveyed by the total station. Those points are well distributed on the whole façade, and they lie on different planes. The position of targets was determined automatically by the software in both cases (circular coded and black/white chess). We also used some other points as Check Points (CP) in order to verify the point clouds accuracy.

The dense clouds were processed in high quality for the orthophoto generation and in medium quality for the point clouds comparison purposes. High-quality dense clouds had respectively about 84 million points for the UAS photogrammetric project and 203 million for the ground photos project.

The mesh models were generated in order to obtain the orthomosaic of the façade. Respect to the specific parameters of Metashape, we decided to disable the interpolation, as to work only with really acquired data and to reduce to the minimum the graphic-computational adjustments implemented by the software.

When generating the orthomosaic, and depending on the photo resolution, Agisoft Metashape propose a different pixel size. For our projects the proposed pixel size was $0.0018 \mathrm{~m}$ for UAS and $0.0009 \mathrm{~m}$ for ground orthophotos. We used 0.002 meters as pixel size for both image sets because this value well fits the purposes of the scale of representation.

In order to compare the results, we used the software Cloud Compare. This software allows to compare point clouds by different algorithms. Among the given possibilities, we used the M3C2 distance computation algorithm, which calculates the local distance between two point clouds along the normal surface direction, which tracks 3D variation in surface orientation (LAGUE et al., 2013). This method computes the distances directly on point clouds (without meshing) and it gives a confidence interval depending on point clouds roughness. It also gives the possibility to remap all the points with a color gradient related to their distance value.

We first used the comparison tool to relate the photogrammetric point clouds with the TLS, considered as a fixed reference. In particular for TLS comparison, we decided to use only a single scan, the central one, to avoid errors related to other scan alignments. Then we compared the point clouds from UAS with the one from ground photos. The last step of our procedure was a visual comparison related to the generated orthophotos. Its aim is to determine the main differences between the two pictures.

First, we saw the general accuracy of the survey by comparing it with the TLS data. Dealing with the comparison tool, we set the maximum distance to compute and to show in the histogram. The value of $3 \mathrm{~cm}$ was enough to deal with errors between point-clouds, without considering evident differences (missing parts of the façade due to the scanner position as the roof and the hidden corner).

The comparison between TLS and UAS photogrammetry data (Figure 5) shows that most of the points are distributed with an absolute distance in a range from -0.0010 to +0.012 meters. In the images, all points have been colored in false colors, according to the distance from the reference. The scale color is in the range between $+0.03 \mathrm{~m}$ and $-0.04 \mathrm{~m}$, where the green colors occupies the $0 \mathrm{~m}$ distance 
By observing the false color map, we notice that some details are missed, especially on the elements that are facing upwards. This is really evident on the dentil decorated moulding, on the bas reliefs and on the window lintel frames.

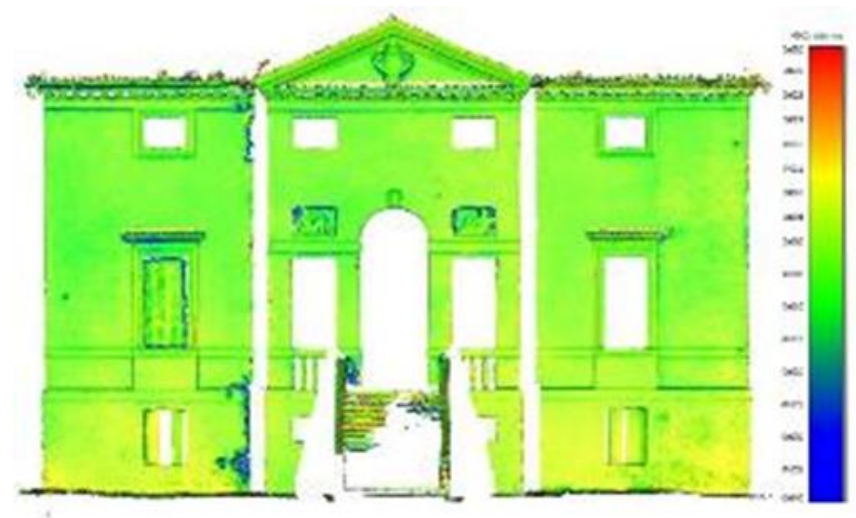

Comparing TLS and terrestrial photogrammetry data (Figure 6), most of the points were distributed with an absolute distance in a range very similar to the previous one, between 0.0012 and $+0.0012 \mathrm{~m}$. Essentially in this comparison, we cannot notice big differences or missing parts because the two data sets were acquired from very similar positions (from the ground). From the color map, we observe a difference in the top left of the façade. Although the absolute value of the error is not significant, it can be assumed that there was some error in the alignment which determinate the different behavior.

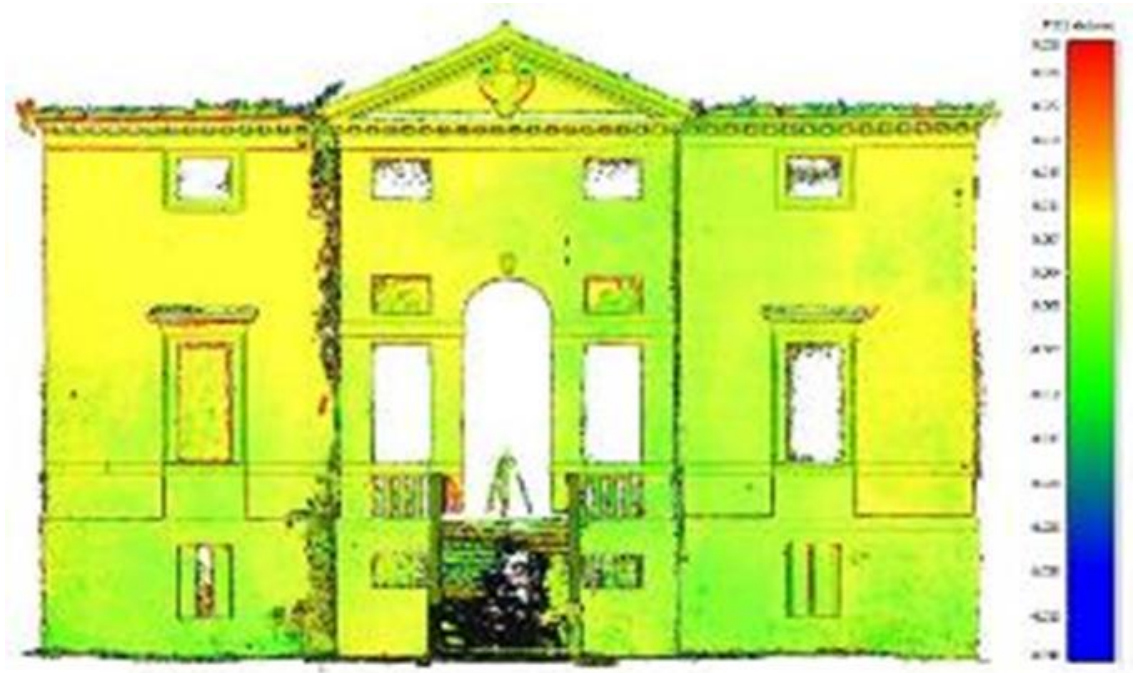

Figure 2. Point clouds comparison between TLS and the UAS photogrammetric model

HE.SU.TECH., 2018.

Figure 7: comparison between the point clouds extracted by the two photogrammetric sets (from ground and from UAS)

Source: HE.SU.TECH., 2018. 
Figure 8: orthophotos obtained by ground and UAV photogrammetry, respectively Source: HE.SU.TECH., 2018.
Figure 9. Details of the decoration of the tympanum, on the main façade. On the left the orthophoto obtained

from the ground, on the right, the one obtained from

Source: HE.SU.TECH., 2018.
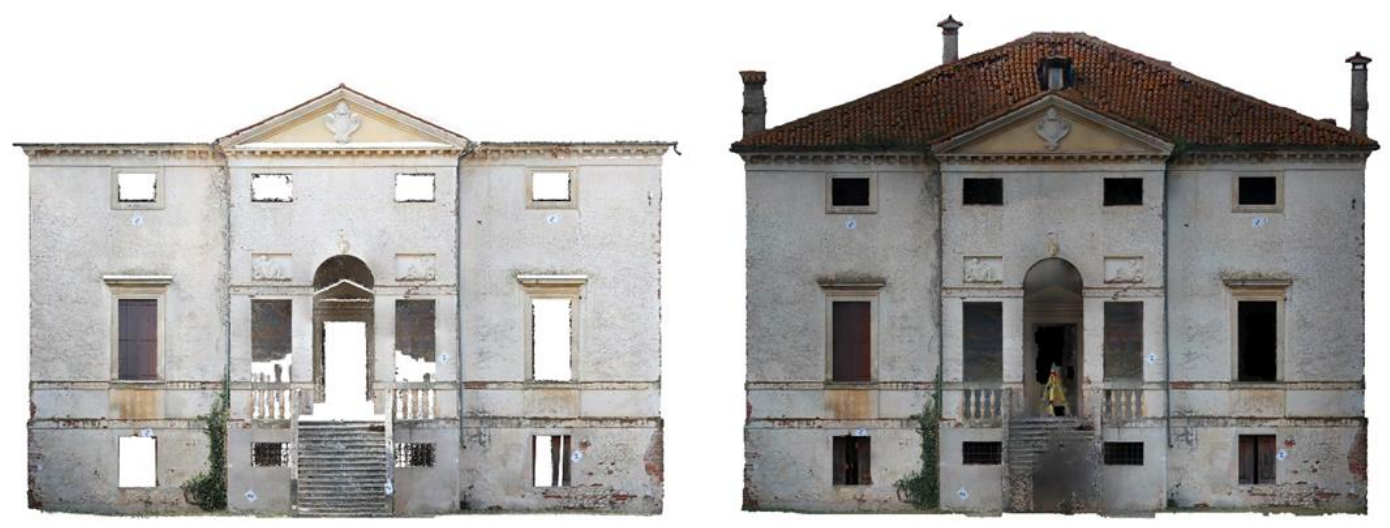

In Figure 8 it is possible to see the produced orthophotos for the study-case façade. The diverse general brightness of the façade is caused by the fact that pictures were taken at different times of the day. It is also possible to notice that there are some macro-differences between the two. The ground photogrammetry orthophoto does not contain the roof, which is, of course, present in the other. We have also to notice that some decorations near the roof eave and the bottom portion of the tympanum are not visible in the one generated from ground photos. The details of the same part in the two orthophotos (Figure 9) describes very clearly this difference in terms of missing parts and details. In the image on the right, indeed, we can see the total lack of the covering and some lacks (called "shadows") immediately above the frame and the decoration; this lack is due to the elements of the façade that come out from the middle floor and "cover"portions of the surface.
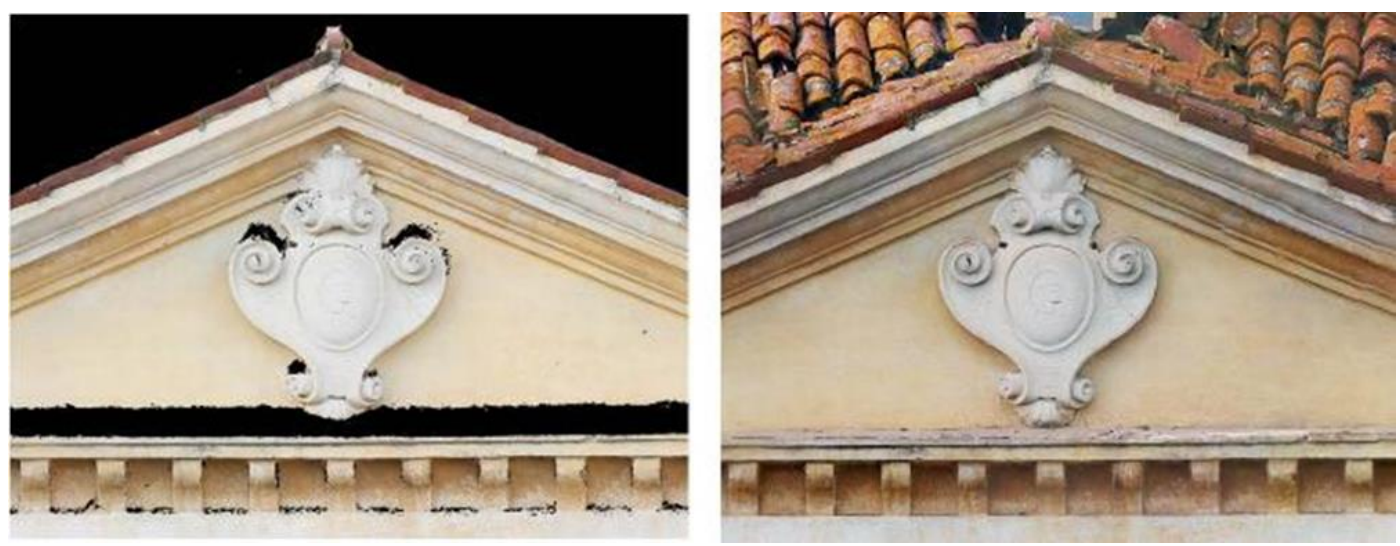

From this comparison case, we can derive some positive and negative elements from both approaches. In particular, with ground photogrammetry, we can use high-resolution cameras and there are no problems of the pixel size on the object (GSD): we can stay, if possible, at a greater distance from the façade (the one calculated by the theoretical approach) and reduce the number of photos to be processed.

The photos can be easily taken by a single operator in (theoretically) any condition and without the need to close the area to other people as it happens with UAS systems that are more dangerous (according to Italian regulation). And there is no need for personnel with a specific license. As a drawback of this approach, some portion of the façade, especially at higher levels, are not visible in the resulting ortho-image. There is also a more technical problem related to 
the different size of GSD all over the façade: the tilted images often involve a very different GSD between the pass part of the photograph and the top part, forcing you to take many more shots or lowering the average value of the GSD.

Moving to UAS photogrammetry, it is evident that there is more freedom of movement, in fact the drone flight can be planned in order to avoid obstacles (using onboard sensors) and staying orthogonally even on higher portions of the façade (CARNIVALI et al., 2018). The drone is also suitable for complex geometries and able to detect even detail not visible from ground (CALANTROPIO et al., 2018).

However, there are some disadvantages due to the size of the low cost camera sensor mounted on the UAS. The number of pictures to obtain the same GSD, compared to the ground survey, increases a lot and the camera has to be closer to the façade. Plus, to use the drone it requires qualified personnel (pilot) with a license and the surveyed area must be protected from the access of people.

In terms of precision, the accuracy of UAS system is slightly lower than that obtained from the ground, but it is suitable anyway for architectural representation. We can conclude that in some cases these two data sets are compatible. For Cultural Heritage purposes, the discriminant elements are the purpose and the scale of the survey; they drive the choice of the most suitable techniques. But we should also consider the possibility to document parts that are difficult to reach or the chance to have not only geometric information but also color.

Photogrammetric survey was also used to document the state of conservation of the roof covers. With the same UAS described above, Dji Spark, nadiral flights were made (with the camera vertically oriented downwards), in order to acquire the rooftop and all the elements connected to it. Also in this case, the data processing was done with the use of targets (black/white checkerboard target, as in Figure 10 detail) measured through the total station and therefore the coordinates belong to the reference system of the whole building. Point clouds and orthophotos were obtained from photogrammetric processing.

Through the orthophoto (Figure 10) it was possible to describe from above the state of conservation of the roof and the nearby buildings. On the other hand, the point clouds were very useful because it integrated those of the interiors: the internal and external point clouds were obtained from the roof covering and it was therefore possible to measure all thicknesses. 
Figure 10: orthophoto from the top of the villa and its annexes, with the detail of a black/white checkerboard target

Source: HE.SU.TECH., 2018.

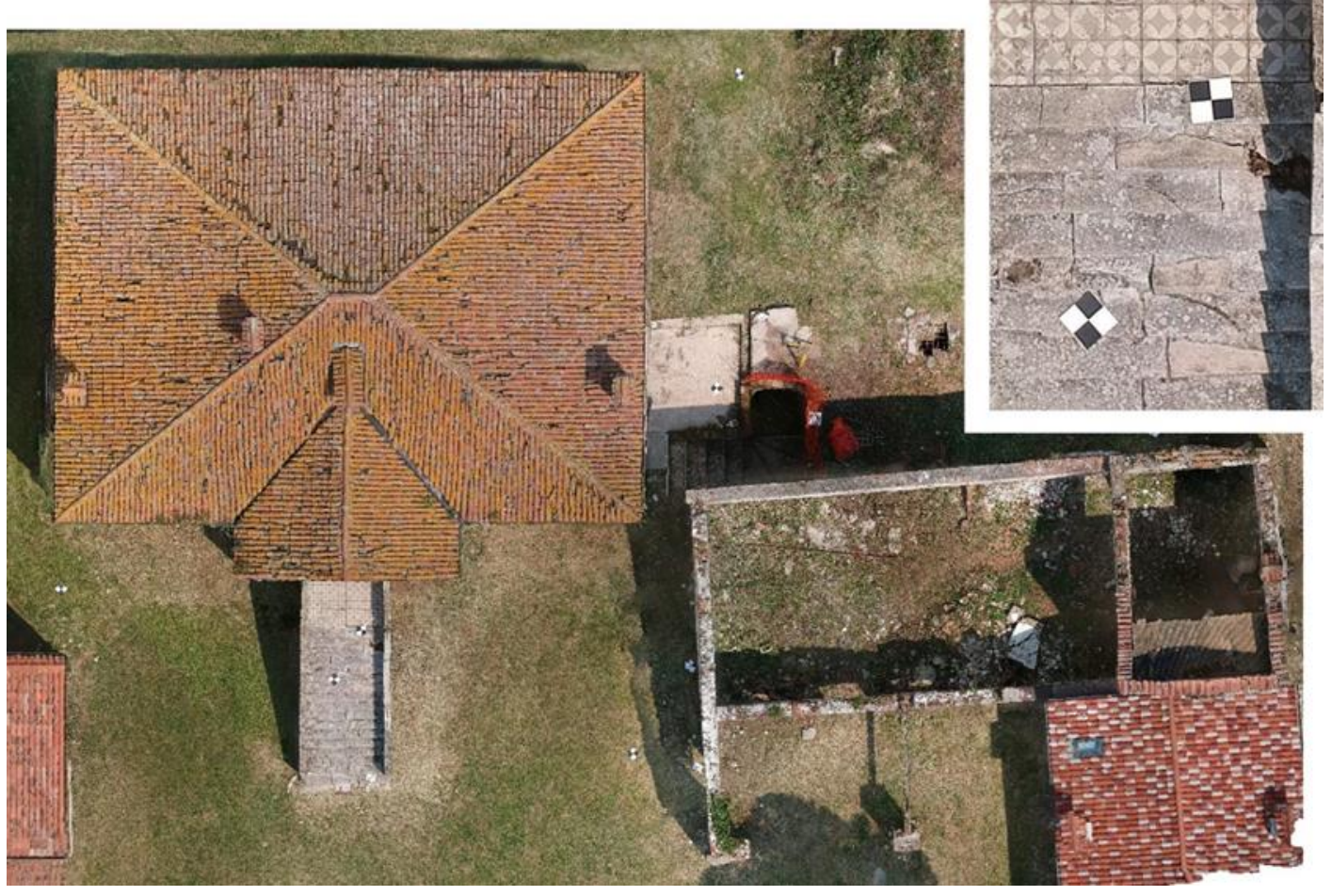

The drone photographs are also an important diagnostic tool at the disposal of conservatives who can, thus, closely observe otherwise inaccessible elements such as eaves and drainpipes (Figure 11).
Figure 11. high detail image from UAS. Detail of the roof

\section{Source:} HE.SU.TECH., 2018.

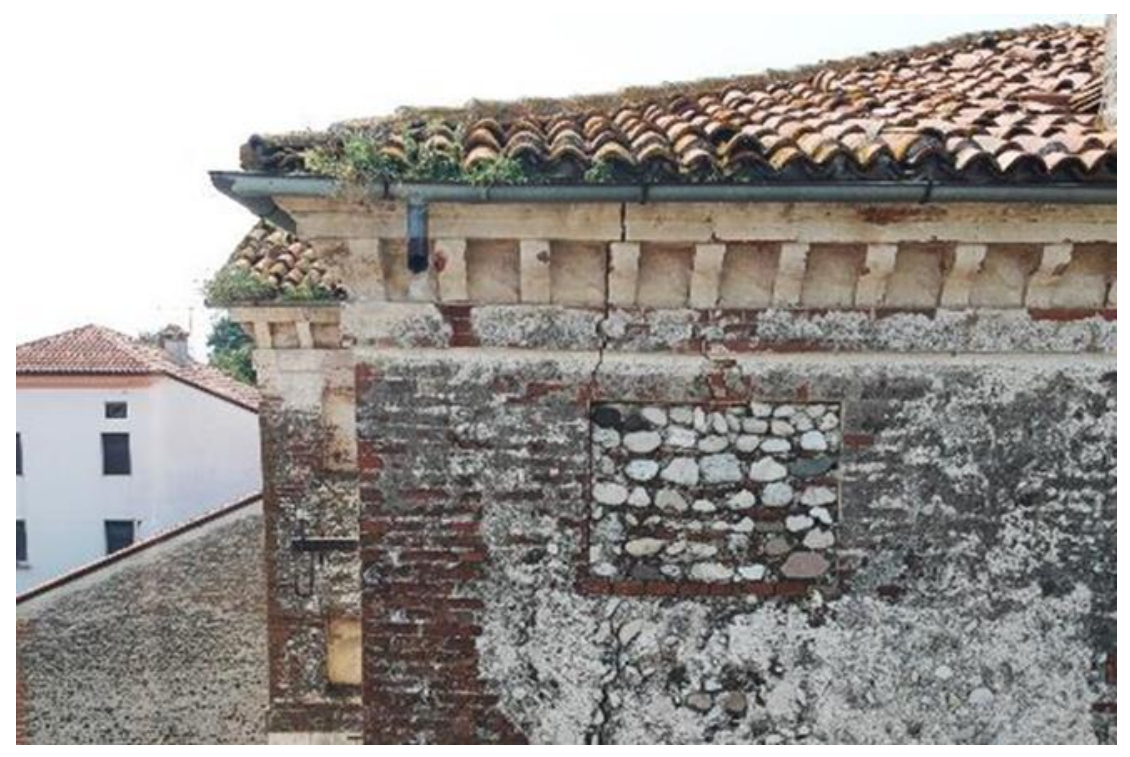




\section{REPRESENTATION TECHNIQUES}

Once the data acquisition and processing phase is over, the first products that are obtained are the point clouds and the orthophotos. Through the former it is possible to proceed with the drawings of the entire building.

There are many applications that allow management of the point clouds. Leica Cloudworx, Leica Jetstream and Autodesk Recap have been used in this work; all these systems share the ability to slice point clouds into user-selected positions and extract thin slices of points that can then be digitized. While in the Architecture, Engineering and Construction industry (AEC), automatic systems that extract plans and sections are researched, these same algorithms often fail when it comes to cultural Heritage, because historic architecture is less regular than the contemporary one and it does not allow excessive simplification, otherwise the risk of not representing the building itself (the subject matter), but only its ideal representation (the idea, the project) arises.

Through these systems, and by projecting the designed elements onto the appropriate reference planes, the traditional representations of architecture are obtained (Figure 12).
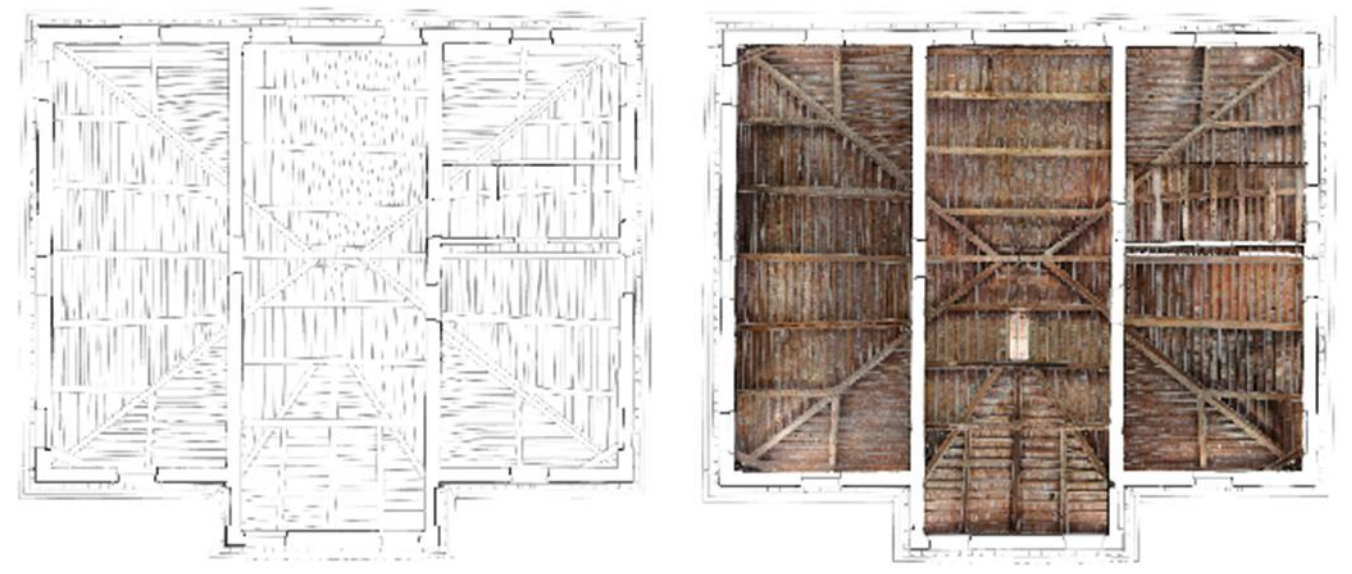

On these representations, however, it is also possible to integrate other information necessary to complete the knowledge of the architecture and to prepare the conservation project. The orthophotos, in fact, inserted as an information layer in the CAD projects allow to have a description of materials that otherwise cannot be deduced from the drawings. They also allow to have precise details on the state of conservation of the materials themselves. For example, it is possible to compile the cracking picture of a façade, indicating the trend of the main cracks and, if known, their depth (Figure 13).

As previously stated, in the case of Villa Forni Cerato the comparison between survey drawings, digitized as described with the modern methods of Geomatics, and the historic ones (in this case the representations of Muttoni and Scamozzi) is of great interest.

Comparing the current plan with the versions of Muttoni and Scamozzi, various inconsistencies can be observed. Such a comparison can be done either through a visual analysis or through the overlap of different layers with transparency. This procedure is very similar to the one used in cartography to compare historical maps of different periods. In general, the comparison involves a first superimposition of the two documents (historical map and current map) obtained through global transformations (scaling, rotation, translation) applied with the same parameters to the whole drawing. Non-conforming global transformations (which therefore do not maintain the internal angles) can also be applied, such as scale variations with different
Figure 12. Given the importance and unusual characteristics of the roof, compared to Palladio's production, the inverted plan of the roof plane is presented. The differences between the drawing on the left (geometry only) and the version on the right (with the orthophoto) are observable

Source:

He.SU. HE.SU.TECH., 2018. 
parameters between $\mathrm{X}$ and $\mathrm{Y}$ axis or shear transformations. A second step of the comparison involves, if necessary, a series of local transformations that require the presence of sufficient control points to be performed.

Figure 13. Longitudinal section of the villa with identification of the reference levels. Through the orthophoto, it is possible to reconstruct the crack pattern of the entire façade. Observe the errors in the orthophotos due to different lighting conditions.

Source: HE.SU.TECH., 2018.

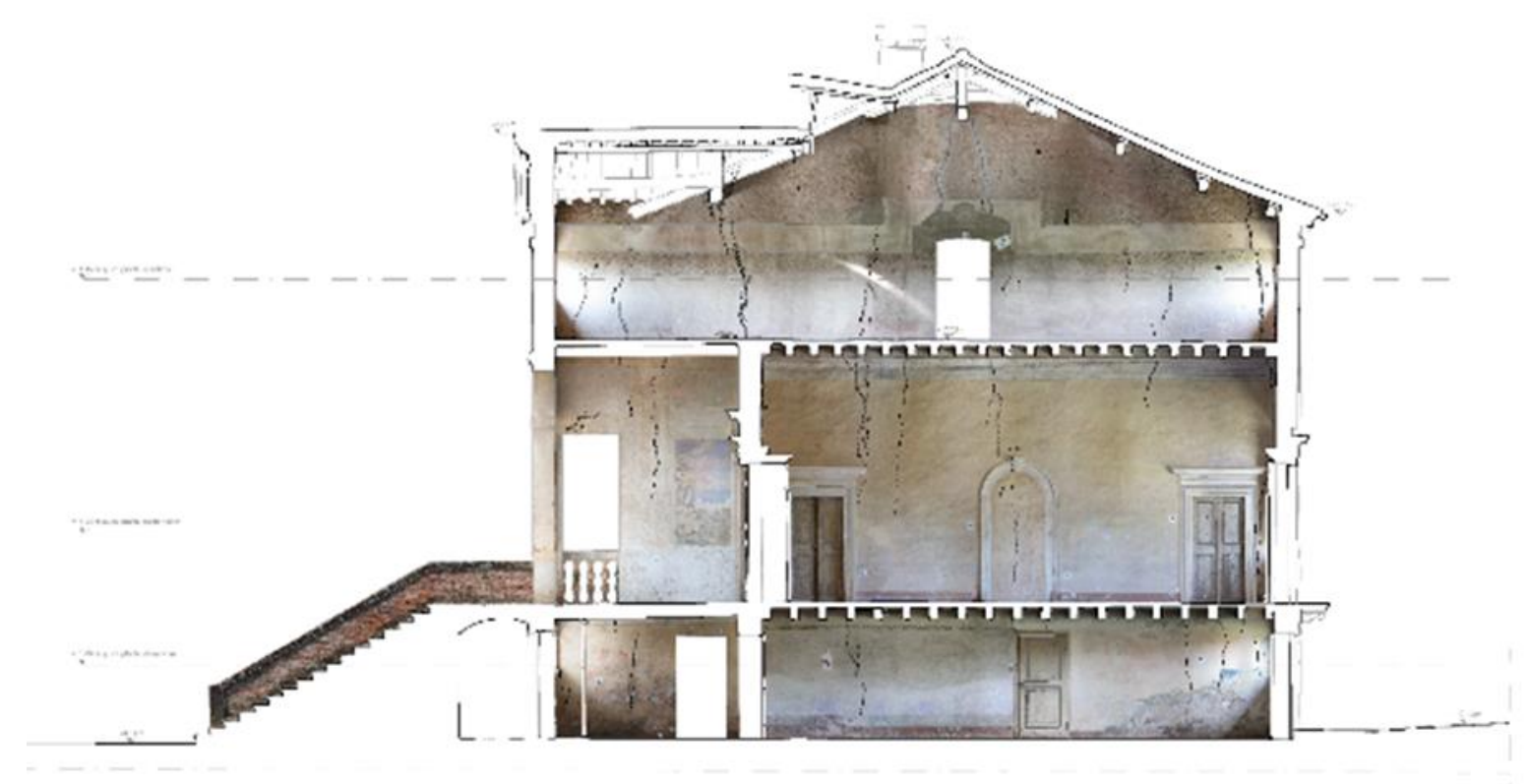

In this case, from the comparison between two different representations, we do not want to define which is more correct, nor to extract reliable metric information from the drawings (at least not at first). In fact, today's data is very controlled, its sources and the processing procedures are known, so questioning it is unnecessary. Nor an analysis of the surveying methods used in the 18th century in the representation of the villa is wanted. Instead, it is much more interesting to try to understand the possibilities offered by the digital approach to the built Heritage. Among them, the possibility of understanding how the villa has been transformed over the centuries. This process is based on the assumption (hypothesis to be verified through in-depth archival study) that what was represented in the 18th century by the two treatise writers was the actual situation at the time.

However, considering this assumption (the drawings represented the "as-built") and observing the plans (Figure 14) we can see that the element that underwent the greatest transformations were the internal staircases. In all three cases the stairs are positioned on the right side of the plan. However, Muttoni (drawing published around 1740) draws them as a double flight staircase that occupies the whole space, while in the representation of Scamozzi (drawing published in 1778) the stairs are spiral and occupy only partially the width of the right sideband. 

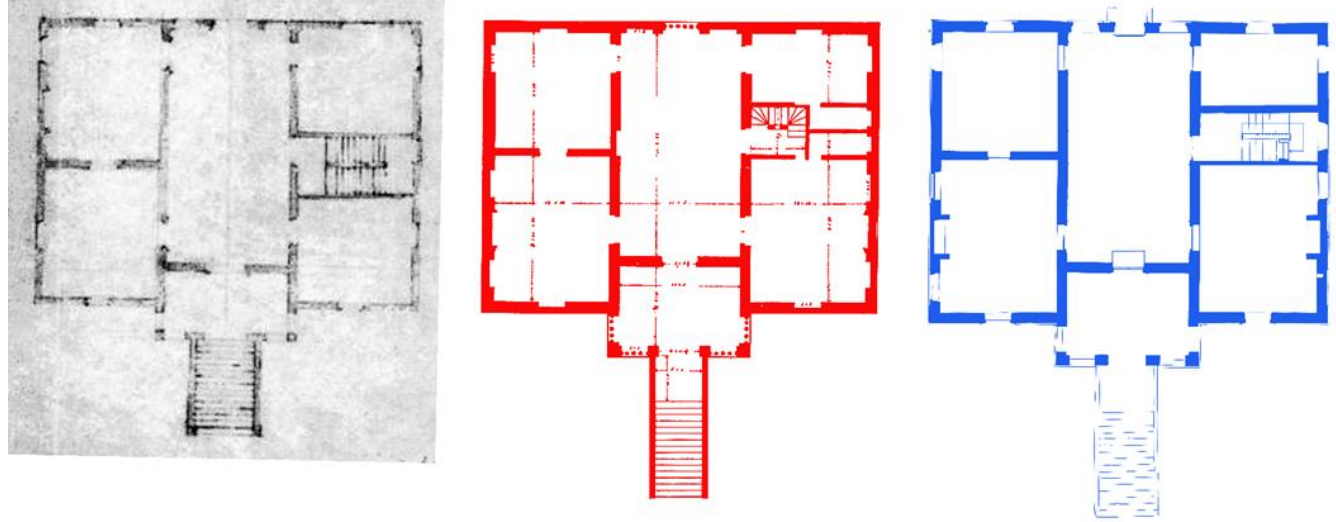

This comparison clearly needs further historical studies, since the version represented by Muttoni is more like to today's, despite being the oldest. Therefore, it is plausible to question if the drawing of the Scamozzi was the output of a survey, a more idealized representation or a reference to other similar cases. The analysis of the exteriors is different. Observing the main façade, in the representation of the Muttoni one notices the presence of a stringcourse on the last level and a frame of the main arch, both elements that are missing from the drawing of the Scamozzi and in the present state. The design of Scamozzi, finally, is more authentic also to the representation of the roof, while the version proposed by Muttoni is very different from the current state.

Since there is no corresponding drawing by Muttoni, the comparison between sections can only be made between Scamozzi and the current configuration (Figure 15). Assuming to draw a section in the same position thought by Scamozzi (a plane that cuts longitudinally the villa, passing through the middle), the greatest differences can be observed in the roofs' geometry. While the external shape of the roof covering and the roof pitches seem identical, a different construction can be observed inside, which determines the division of the central space into two parts.

This comparison, which is not exhaustive, highlights the need to have a reliable and metrically correct data, as an essential condition for the knowledge of the building. At the same time, however, it also demonstrates the need for an interdisciplinary approach to architecture that combines more technical aspects with historical ones (ADAMI et al., 2019).
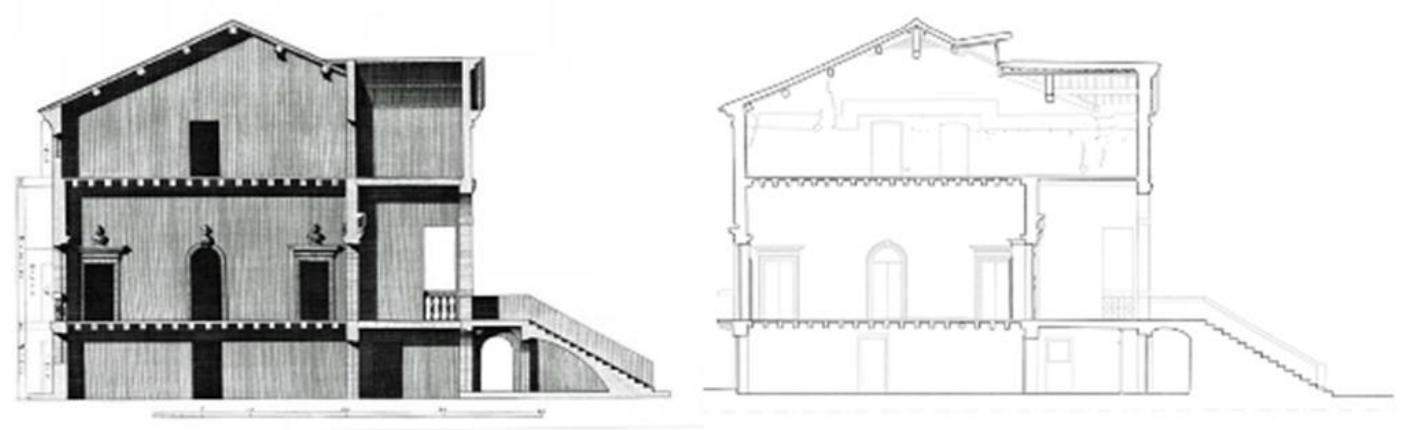

Moreover, in the field of representation, the HE.SU.TECH. Laboratory is working on the topic of HBIM to test the validity of the method (the use of building information models) also for historical building (ADAMI et al., 2017).
Figure 14. comparison between the floor plans of Villa Forni Cerato. From left: Muttoni (1740), Scamozzi (1778), He.Su.Tech. (2018). The drawings were represented at the same scale, and rotation, making the upper side coincide

Source: HE.SU.TECH., 2018.

Figure 15. comparison between the section drawings of Villa Forni Cerato. Left Scamozzi (1778), right He.Su.Tech. (2018). The sections have been represented at the same scale

Source: HE.SU.TECH., 2018. 
The BIM systems were born as a support for the design, construction and maintenance of new buildings; this research aims to verify the applicability of the same approach to the case of cultural assets and heritage. Starting from the survey data, the theme of greatest interest is the geometric generation of the BIM model, as it is an operation that must seek its own balance between an effective and precise representation (difficult to achieve with a parametric approach) and an ideal representation (distance from the needs of the building site and the architectural project). For example, in many cases walls are not perfectly linear because of deformations, and also beam systems are not so regular; these are some of the issues that must be resolved when talking about parametric modeling of historical buildings. The modeling of Villa Forni Cerato, set in the Autodesk Revit software, but not yet completed, has already highlighted that it is necessary to proceed by successive levels of refinement and that it is essential to immediately recognize the objective of the BIM model, so that all the choices can be calibrated according to the final objective. In fact, it will be necessary to create a federated model in which every single component (architectural, structural, and plant model) has its own level of definition (LOD), level of information (LOI), level of Information Needed (LOIN) in relation to its actual use (Figure 16).

Figure 16. Construction phases of the HBIM model. Left the comparison between the parametric model and the point clouds, the basis of the modeling. On the right the general model, with the construction of the beam systems for the central hall on the main floor and for the attic.

Source:

He.Su.Tech, Daniele Deplano Internship results, 2019

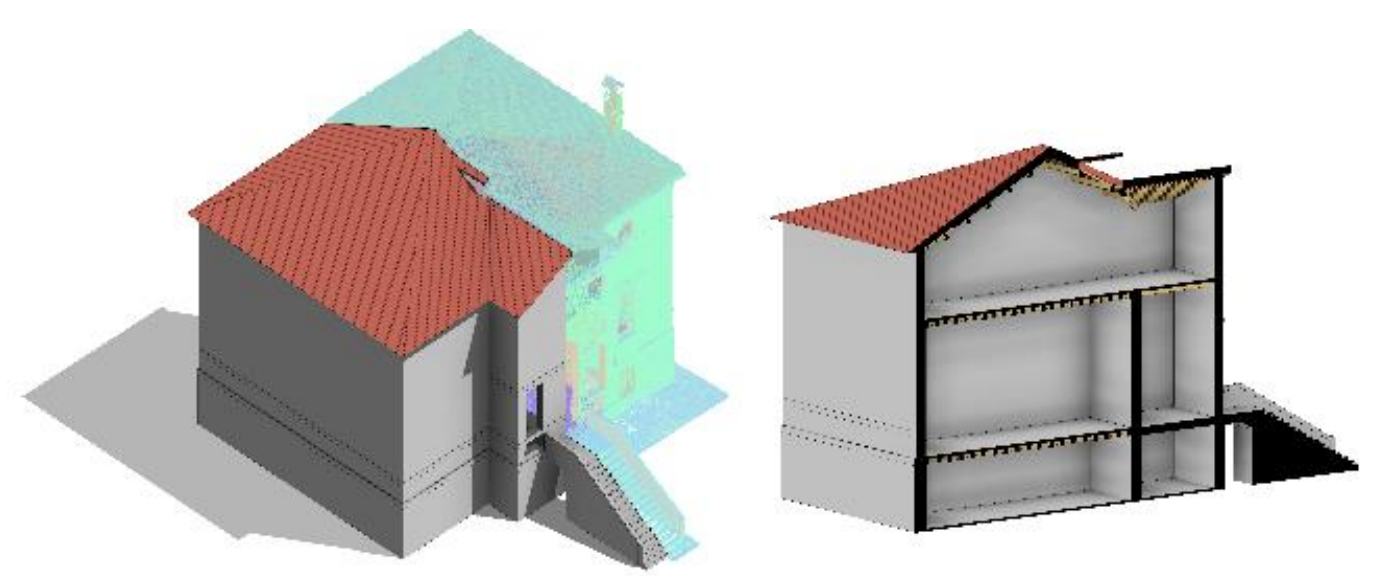

\section{CONCLUSIONS}

In this article, we tried to highlight the importance of Geomatics in the conservation of Cultural Heritage through the description of the activity of HE.SU.TECH., Politecnico di Milano. The group of researchers of the Polo di Mantova by combining academic research and practice and, through the numerous collaborations with Italian and international institutions and companies, demonstrates the importance of the digitization of Architectural Heritage. The documentation, representation and preservation are carried out through the integration of different technologies and a multidisciplinary approach.

Laser scanning and photogrammetry today are accessible and widespread tools and methods, but they require attention, especially when it is necessary to integrate different data in a single system, as so often is the case. The integration of the above-mentioned data responds to the knowledge requirement of architecture: the geometry extracted from the TLS point clouds is completed and enriched through the color information extracted from photogrammetry. This integration is even more effective if it allows to see the object from different points of view. This is the case of the UAS, which allows you to see parts that are usually hidden or inaccessible. 
The experiences described in the article also show that these data have the same metric reliability as those surveyed by laser scanning or terrestrial photogrammetry.

Raster and vector integration (survey drawings with orthophotos) is an established practice that meets the different needs of the designer/restorer. Today, however, attempts are being made to encourage communication between all operators in the building process and therefore new approaches are being tested to facilitate data exchange. Villa Forni Cerato is an example of this approach, where modeling choices relate to the use of the model (conservation, structural rehabilitation, energy requalification, valorization). The attention is also focused on informative modeling, necessary to complete the description of the asset with added documents, reports, photographs, and other works that be linked to the geometric model.

Meanwhile, there is a strong need, especially in the case of significant architectures such as Palladio's villa, for a multidisciplinary approach, in which the various contributions do not end in themselves, but become an integral part of the architectural project; recognizing the transformations of an architecture in the course of its history does not only influence the stylistic or architectural choices (such as restoring previously existing wall openings). Structural and plant design also benefit from this knowledge and can thus help develop more precise and realistic calculation models.

All the above observations refer to the operation carried out by Villa Forni Cerato Srl which, with the aim of recovering the asset and bringing it back into use, has tried to bring together all the necessary competences through unified management.

\section{Acknowledgement}

This research is part of the architectural survey of the Palladian villa commissioned the Mantua Campus of Politecnico di Milano and financed by Villa Forni Cerato Foundation

Thanks to the USP Institute of Architecture and Urbanism for the infrastructure provided for the "Fotogrametria + Patrimônio" workshop and to São Paulo Research Foundation (FAPESP) for financing Project no. 2018 / 18958-0.

\section{References}

AMORIM, Arivaldo L.; GROETELAARS, Natalie J. A fotogrametria digital na documentação do Patrimônio Arquitetônico. In: FORUM PATRIMÔNIO: AMBIENTE CONSTRUÍDO E PATRIMÔNIO SUSTENTÁVEL, 2008, Belo Horizonte. Anais [...] Belo Horizonte: UFMG, 2008, vol.2, n.2, p.92-105.

ACHILLE, Cristiana; ADAMI, Andrea; CHIARINI, Silvia; CREMONESI, Stefano; FASSI, Francesco; FREGONESE, Luigi; TAFFURELLI, Laura. UAV-based photogrammetry and integrated technologies for architectural applications. Methodological strategies for the after-quake survey of vertical structures in Mantua (Italy). Sensors, 2015, 15 (12), pp. 15520-39.

ADAMI, Andrea; FREGONESE, Luigi; ROSIGNOLI, Olga; SCALA, Barbara; TAFFURELLI, Laura; TRECCANI, Daniele. Geometric survey data and historical sources interpretation for HBIM process: the case of Mantua cathedral façade. Int. Arch. Photogramm. Remote Sens. Spatial Inf. Sci., XLII-2/W11, 29-35, https://doi.org/10.5194/isprs-archives-XLII-2-W11-29-2019, 2019.

ADAMI, Andrea; SCALA, Barbara; SPEZZONI, Anna. Modelling and accuracy in a BIM environment for planned conservation: The Apartment of Troia of Giulio Romano. Int. Arch. Photogramm. Remote 
Sens. Spatial Inf. Sci., XLII-2/W3, 17-23, https://doi.org/10.5194/isprs-archives-XLII-2-W3-17-2017, 2017.

BERTOZZI SCAMOZZI, Ottavio. Le fabbriche e i disegni di Andrea Palladio, Vicenza, 1778, Vol II.

CALANTROPIO, Alessio; CHIABRANDO, Filiberto; RINAUDO, Fulvio; TEPPATI LOSÈ, Lorenzo. Use and evaluation of a short-range small quadcopter and a portable imaging laser for built heritage 3D documentation. Int. Arch. Photogramm. Remote Sens. Spat. Inf. Sci. - ISPRS Arch., vol. 42, 2018, no. 1, pp. 71-78.

CARNEVALI, Laura; IPPOLITI, Elena, F. LANFRANCHI, Fabio; MENCONERO, Sofia; RUSSO, Michele; RUSSO, Valentina. Close-range mini-UAVs photogrammetry for architecture survey, in Int. Arch. Photogramm. Remote Sens. Spatial Inf. Sci., 2018, XLII-2, 217-224.

CEVESE, Renato. II villino Cerato di Montecchio Precalcino: un problema attribuzionistico. in Chastel, André; Cevese, Renato. Andrea Palladio. Nuovi contributi. Milano, Electa, 1990.

FASSI, Francesco; CAMPANELLA, Christian. From daguerreotypes to digital automatic photogrammetry. Applications and limits for the built heritage project. Int. Arch. Photogramm. Remote Sens. Spatial Inf. Sci., XLII-5/W1, 313-319, https://doi.org/10.5194/isprs-archives-XLII-5W1-313-2017, 2017.

FREGONESE, Luigi; TAFFURELLI, Laura; ADAMI, Andrea. BIM Application for the Basilica of San Marco in Venice: Procedures and Methodologies for the Study of Complex Architectures. Latest Developments in Reality-Based 3D Surveying and Modelling MDPI, Basel, Switzerland, 2018; pp. 348373.

LAGUE, Dimitri; BRODU, Nicolas; LEROUX, Jerome. Accurate 3D comparison of complex topography with terrestrial laser6scanner: Application to the Rangitikei canyon (N-Z). ISPRS Journal of Photogrammetry and Remote Sensing, 2013, LXXXII, pp. 10-26.

MUTTONI, Francesco. Architettura di Andrea Palladio Vicentino con le osservazioni dell'Architetto N.N.Venezia: 1740, I, Indice.

REMONDINO, Fabio; SPERA, Maria Grazia, NOCERINO, Erica; MENNA, Fabio; NEX, Francesco. State of the art in high density image matching. Photogram Rec, 29: 144-166, 2014, doi:10.1111/phor.12063;

RUSKIN, John. A lâmpada de memória/ John Ruskin. tradução e apresentação. Maria Lucia Bressan Pinheiro. Cotia-SP: Atelia Editoriale, 85p. 2008.

STYLIANIDIS, Efstratios; REMONDINO, Fabio. 3D recording, documentation and management of cultural Heritage. Caithness (Scotland): Whittles Publishing, cop. 2016.

VIZIOLI, Simone H. T.; ADAMI, Andrea; FREGONESE, Luigi; TAFFURELLI, Laura; HELDER, Jacopo. O Laboratório HE.SU.TECH.: a pesquisa acadêmica aliada à prática aplicada na documentação, representação e preservação do Patrimônio Arquitetônico. In: ENCONTRO BRASILEIRO DE MODELAGEM DA INFORMAÇÃO DA CONSTRUÇÃO E PATRIMÔNIO CULTURAL, 1., 2019, São Carlos, SP. Anais [...]. Campinas: IAU-USP, 2019.

Andrea Adami andrea.adami@polimi.it

Luigi Fregonese luigi.fregonese@polimi.it

Simone Helena Tanoue Vizioli simonehtv@usp.br

Laura Taffurelli laura.taffurelli@polimi.it

Daniele Treccani daniele.treccani@polimi.tt

Olga Rosignoli olga.rosignoli@polimi.it

Jacopo Helder jacopo.helder@polimi.it 